\title{
Effect of Different Dietary Geometric Mean Particle Length and Particle Size Distribution of Oat Silage on Feeding Behavior and Productive Performance of Dairy Cattle
}

\author{
C. Leonardi, ${ }^{1}$ K. J. Shinners, ${ }^{2}$ and L. E. Armentano ${ }^{1}$ \\ ${ }^{1}$ Department of Dairy Science and \\ ${ }^{2}$ Department of Biological Systems Engineering, University of Wisconsin, Madison 53706
}

\begin{abstract}
Twenty lactating Holstein cows (5 primiparous and 15 multiparous) were used in a $5 \times 5$ Latin Square design, with 5 treatments and 3 periods of $21 \mathrm{~d}$ each. Diets contained $25 \%$ corn silage, $25 \%$ oat silage, and $50 \%$ concentrate (dry matter basis). The 5 treatments tested in the experiment were long oat silage (LOS), medium oat silage (MOS), fine from long oat silage (FLOS), fine from medium oat silage (FMOS), and half LOS plus half FLOS (LFLOS). The geometric mean particle length (GMPL) of the diets was $6.68,5.19$, $4.46,4.35$, and $5.39 \mathrm{~mm}$ for LOS, MOS, FLOS, FMOS, and LFLOS, respectively. The LFLOS was designed to provide dietary GMPL similar to MOS, but with a more bimodal particle size distribution (PSD). Linear and quadratic effects of GMPL were tested, based on the mean GMPL of the feed actually consumed (cGMPL). Contrasts were used to test for the effect of different PSD (MOS vs. LFLOS) and to test for differences between FMOS and FLOS, which would indicate unequal fermentations in the MOS and LOS silos. No differences were detected between FMOS and FLOS in most of the variables measured. Increasing cGMPL linearly decreased dry matter intake, milk production, and milk protein percentage and yield without affecting milk fat percentage, milk fat yield, ruminal $\mathrm{pH}$, and ruminal volatile fatty acid concentration. Although cows fed diets with increasing cGMPL spent more time eating and chewing per day and per kilogram of dry matter intake, there was no effect of cGMPL on rumen $\mathrm{pH}$. Feeding medium oat silage increased milk fat percentage and yield compared with feeding a mixture of long and fine oat silage.
\end{abstract}

(Key words: oat silage, particle size distribution, geometric mean particle length)

Received June 14, 2004.

Accepted September 27, 2004.

Corresponding author: L. E. Armentano; e-mail: learment@ wisc.edu.
Abbreviation key: cGMPL = geometric mean particle length of the diet consumed; dGMPL = dietary geometric mean particle length; FLOS = fine from long oat silage; FMOS = fine from medium oat silage; GMPL = geometric mean particle length; LFLOS = $50 \%$ long oat silage and $50 \%$ fine from long oat silage; LOS = long oat silage; $\mathbf{M F}=$ multiparous, fistulated; MOS = medium oat silage; NDFI = neutral detergent fiber intake; peNDF = physically effective neutral detergent fiber; PSD = particle size distribution.

\section{INTRODUCTION}

To maintain rumen fermentation and cow health, NRC (2001) recommends feeding dairy cattle a minimum of $25 \%$ dietary NDF. To ensure a minimum amount of NDF with an adequate physical structure to stimulate chewing activity, a minimum of $19 \%$ dietary forage NDF also has been recommended (NRC, 2001). However, forage particle length can vary extremely, and it is not clear what measurement of a forage physical characteristic would best predict the animal response.

Two terms have been introduced to distinguish between the ability of a feed to stimulate chewing activity and its ability to maintain milk fat percentage: effective NDF and physically effective NDF (peNDF; Mertens, 1997). Effective NDF is defined as the capability of the NDF of a feed to replace forage NDF in maintaining milk fat percentage. Physically effective NDF is defined as feed NDF that stimulates chewing and is therefore related to feed particle size (Mertens, 1997). The concept of peNDF has been introduced to unify into a single measurement the NDF concentration and the physical characteristics of a feed. One practical system developed to measure feed peNDF multiplies NDF concentration by the material retained on a sieve with an aperture of $1.18 \mathrm{~mm}$ (Mertens, 1997). The intake of peNDF calculated as described by Mertens (1997) has been significantly correlated with total time spent chewing $(\mathrm{r}=0.52$; Beauchemin et al., 2003). However, forages with a similar percentage of material retained above a screen of $1.18 \mathrm{~mm}$ can 
be chopped at different lengths. Forages with equal amounts of material above the 1.18-mm screen can have much different geometrical mean particle length (GMPL) because of the presence of differing proportions of very long and intermediate length particles. It is possible that GMPL will accurately predict the physical effectiveness of the diet across these different particle size distributions (PSD). The GMPL can be calculated with a portable system comprising 3 screens and a pan (ANSI, 2001) or by a laboratory device comprising 5 screens and a pan (ANSI, 1998). Analyses of the former are commercially available from Cumberland Valley Analytical Services (Hagerstown, MD) and UW Soil \& Forage Analysis Laboratory (Marshfield, WI) and for the latter are commercially available from Dairyland Laboratories, Inc. (Arcadia, WI). It is also possible that simply stating the mass above a certain screen, which is easier to measure than GMPL, would describe physical effectiveness but that a screen $>1.18$ $\mathrm{mm}$ may be most useful. A third possibility is that introducing more long particles increases physical effectiveness more than can be accounted for by increasing GMPL. The primary objective of this study was to address whether GMPL alone accurately predicted the physical effectiveness of a mixed ration fed to lactating dairy cattle without considering PSD. Because GMPL and the fraction above certain screens are generally highly confounded, we purposely manipulated the oatlage content of 2 of our diets to provide similar GMPL with differing PSD. In addition, oat silage was processed to various lengths to quantify the response of lactating cows across a range of particle sizes derived from forage.

\section{MATERIALS AND METHODS}

\section{Animals}

Fifteen multiparous and 5 primiparous lactating Holstein cows were assigned to a replicated $5 \times 5$ Latin Square design, with periods of $21 \mathrm{~d}$. The trial lasted only 3 periods of the 5 planned. Eight multiparous cows were ruminally fistulated. One square consisted of multiparous, fistulated (MF) cows with the highest milk production among the previously fistulated cows assigned to the experiment. A second square consisted of multiparous cows with the highest milk production among nonfistulated multiparous cows. A third square consisted of the remaining multiparous cows, including the 3 fistulated cows not included in the MF group. A fourth square consisted of primiparous cows. At the beginning of the study, MF cows averaged $62 \pm 9$ (average $\pm \mathrm{SD}) \mathrm{DIM}$ and produced $51.6 \pm 2.4 \mathrm{~kg}$ of milk daily, the square of multiparous cows with the highest milk production averaged $58 \pm 28$ DIM and produced
Table 1. Ration composition.

\begin{tabular}{|c|c|c|c|}
\hline \multirow[b]{2}{*}{ Ingredient } & \multicolumn{3}{|c|}{$\operatorname{Diet}^{1}$} \\
\hline & $\begin{array}{l}\text { FMOS + } \\
\text { MOS }\end{array}$ & LFLOS & $\begin{array}{l}\text { FLOS + } \\
\text { LOS }\end{array}$ \\
\hline & & $00 \mathrm{~g}$ of $\mathrm{D}$ & \\
\hline Long oat silage & - & 12.6 & 25.1 \\
\hline Medium oat silage & 25.1 & 12.5 & - \\
\hline Corn silage & 25.1 & 25.1 & 25.1 \\
\hline Corn grain ground & 27.2 & 27.2 & 27.2 \\
\hline Roasted soybeans & 9.6 & 9.6 & 9.6 \\
\hline Soybean meal, $48 \% \mathrm{CP}$ & 9.2 & 9.2 & 9.2 \\
\hline Blood meal & 0.8 & 0.8 & 0.8 \\
\hline Tallow & 0.8 & 0.8 & 0.8 \\
\hline Calcium carbonate & 1.0 & 1.0 & 1.0 \\
\hline Dicalcium phosphate & 0.4 & 0.4 & 0.4 \\
\hline Trace mineral salt ${ }^{2}$ & 0.5 & 0.5 & 0.5 \\
\hline Vitamin $\operatorname{mix}^{3}$ & 0.3 & 0.3 & 0.3 \\
\hline
\end{tabular}

${ }^{1} \mathrm{FMOS}=$ Fine from medium oat silage, $\mathrm{MOS}=$ medium oat silage, FLOS $=$ fine from long oat silage, LFLOS $=50 \%$ long oat silage and $50 \%$ fine from long oat silage, and LOS = long oat silage.

${ }^{2}$ Contained $0.55 \% \mathrm{Mn}, 0.55 \% \mathrm{Zn}, 0.35 \% \mathrm{Fe}, 0.14 \% \mathrm{Cu}, 0.008 \% \mathrm{I}$, $0.006 \%$ Se, and $0.002 \%$ Co.

${ }^{3}$ Contained $3304 \mathrm{IU} / \mathrm{g}$ of vitamin A, $1101 \mathrm{IU} / \mathrm{g}$ of vitamin D, and $11 \mathrm{IU} / \mathrm{g}$ of vitamin $\mathrm{E}$.

$48.6 \pm 1.7 \mathrm{~kg}$ of milk daily, the square of multiparous cows with the lowest milk production averaged $56 \pm$ $31 \mathrm{DIM}$ and produced $39.9 \pm 4.2 \mathrm{~kg}$ of milk daily, and the square of primiparous cows averaged $65 \pm 28 \mathrm{DIM}$ and produced $33.1 \pm 1.9 \mathrm{~kg}$ of milk daily. The sequence of treatments was selected to balance for residual effects. Cows were housed and fed individually in a tiestall and stanchion barn and had free-choice access to water. The Animal Care Committee of the College of Agricultural and Life Sciences of the University of Wisconsin-Madison approved all animal procedures.

\section{Diets}

Diets were mixed once daily and fed for ad libitum intake twice daily at 1100 and $1600 \mathrm{~h}$. The amount of feed offered was adjusted daily to obtain approximately 10 to $15 \%$ orts (as-fed basis). Cows were allowed to exercise daily from $0800 \mathrm{until} 1100 \mathrm{~h}$ and had access to feed for approximately $19 \mathrm{~h} / \mathrm{d}$. Diets were formulated to be isonitrogenous and isoenergetic and to have similar NDF concentrations. All diets contained 25.1\% corn silage, $25.1 \%$ oat silage, and $49.8 \%$ concentrate (DM basis, Table 1) and had similar chemical composition, which was mathematically calculated from individual feedstuff analytical values (Table 2). Small differences in diets' chemical composition were due to unequal chemical composition of oat silages (Table 2). Treatment differences were due to oat silage having either different GMPL or PSD. Treatments consisted of long oat silage (LOS), medium oat silage (MOS), 
Table 2. Chemical composition of forages and diets.

\begin{tabular}{|c|c|c|c|c|c|}
\hline \multirow[b]{2}{*}{ Item } & \multicolumn{3}{|c|}{ Forage $^{1}$} & \multicolumn{2}{|c|}{$\operatorname{Diet}^{2}$} \\
\hline & $\begin{array}{l}\text { Long } \\
\text { OS }\end{array}$ & $\begin{array}{l}\text { Medium } \\
\text { OS }\end{array}$ & CS & $\begin{array}{l}\text { FMOS + } \\
\text { MOS }\end{array}$ & $\begin{array}{l}\text { FLOS + } \\
\text { LFLOS + LOS }\end{array}$ \\
\hline \multirow[t]{2}{*}{$\mathrm{DM}, \mathrm{g} / 100 \mathrm{~g}$ (as fed) } & 30.2 & 28.5 & 36.0 & 47.3 & 48.5 \\
\hline & & & \multicolumn{2}{|c|}{$(g / 100 \mathrm{~g}$ of $\mathrm{DM})$} & \\
\hline $\mathrm{CP}$ & 14.5 & 14.0 & 8.2 & 18.0 & 18.2 \\
\hline NDF & 53.3 & 54.9 & 33.8 & 26.2 & 25.8 \\
\hline $\mathrm{ADF}$ & 36.8 & 38.0 & 22.3 & 17.4 & 17.1 \\
\hline $\mathrm{NFC}^{3}$ & 20.2 & 19.1 & 50.7 & 42.5 & 42.7 \\
\hline Fatty $\operatorname{acid}^{4}$ & 1.4 & 1.3 & 2.7 & 6.3 & 6.3 \\
\hline $\mathrm{Ash}^{5}$ & 10.6 & 10.7 & 4.6 & 7.0 & 7.0 \\
\hline
\end{tabular}

fine rechopped long oat silage (FLOS), fine rechopped medium oat silage (FMOS), and half LOS plus half FLOS oat silage (LFLOS). Oat silage and not alfalfa silage was used in this experiment to obtain a more uniform particle size distribution. Oats have the characteristic of having one culm and therefore less branching than alfalfa if harvested before heading, which was hypothesized to produce a more homogeneous product from chopping. The GMPL of diets offered (dGMPL) was $6.68,5.19,4.46,4.35$, and $5.39 \mathrm{~mm}$ for LOS, MOS, FLOS, FMOS, and LFLOS, respectively (Figure 1). Long and MOS were obtained directly from the field. Oats were cut in the morning and wilted in rows for $24 \mathrm{~h}$. The following afternoon, every other row was chopped with a conventional forage harvester (Gehl-850; Gehl Co., West Bend, WI) equipped with 8 knives and the 15-teeth feed roll drive sprocket for the medium length. The long material was obtained from the remaining rows with the same machine but with only 2 knives and the 21-teeth feed roll drive sprocket. Long and MOS were stored in 2 separate 2.4-m diameter silo bags. The 2 fine oat silages (FMOS and FLOS) were obtained daily just before feeding by rechopping the LOS and MOS. This further size reduction was done with a stationary recutter/blower (Gehl FB-88; Gehl Co.) equipped with a 7.6-cm nominal size openings screen. A buffered acid preservative (Ultra CURB; Kemin, Des Moines, IA) containing 82\% total acids, which included propionic, acetic, benzoic, and sorbic acid, was applied during and after ensiling at $1.8 \mathrm{~kg} /$ tonne of fresh material to reduce spoilage. The combination of low DM content, a hot and humid summer, and low feeding rate favored spoiling during the second period (June). Therefore, to feed unspoiled material, significant amounts of silage were discarded, leaving adequate oat silage to complete only 3 periods of the 5 planned. Corn silage was also rechopped daily utilizing the same recutter and screen previously described for the oat silage. Corn silage was rechopped to minimize its effect on GMPL and PDS.

\section{Feed Sampling and Analysis}

Diets were adjusted weekly to account for forage DM fluctuation. Feed samples were collected once during the last week of each experimental period, dried at $60^{\circ} \mathrm{C}$ for $48 \mathrm{~h}$, ground to pass through a 1-mm screen (Wiley Mill; Arthur H. Thomas, Philadelphia, PA), and analyzed for DM, OM, CP, NDF, ADF, and fatty acid. Orts were sampled during the last $5 \mathrm{~d}$ of each period and composited by animal proportionally to the weight of feed refused each day. The composite ort samples were dried at $60^{\circ} \mathrm{C}$ for $48 \mathrm{~h}$ and analyzed for DM and NDF. Samples of orts and diets were collected for PSD determination on $\mathrm{d} 7$ and 21 of each period to determine feed sorting. Particle size distribution of forages, diets, and orts was determined by sieving samples using the Wisconsin Particle Size Separator in accordance with the ASAE Standard S424.1 protocol (ANSI, 1998). Geometric mean particle length was calculated assuming a mean length of $48 \mathrm{~mm}$ for the material retained on the top screen of the separator, which has 5 square-hole screens. In descending order from the top screen, the diagonal openings are $26.9,18,8.98$, 5.61 , and $1.65 \mathrm{~mm}$ and a pan.

The analytical DM was determined by oven drying at $100^{\circ} \mathrm{C}$ for $24 \mathrm{~h}$, and $\mathrm{OM}$ was determined by ashing at $550^{\circ} \mathrm{C}$ for $12 \mathrm{~h}$. Crude protein content was deter- 


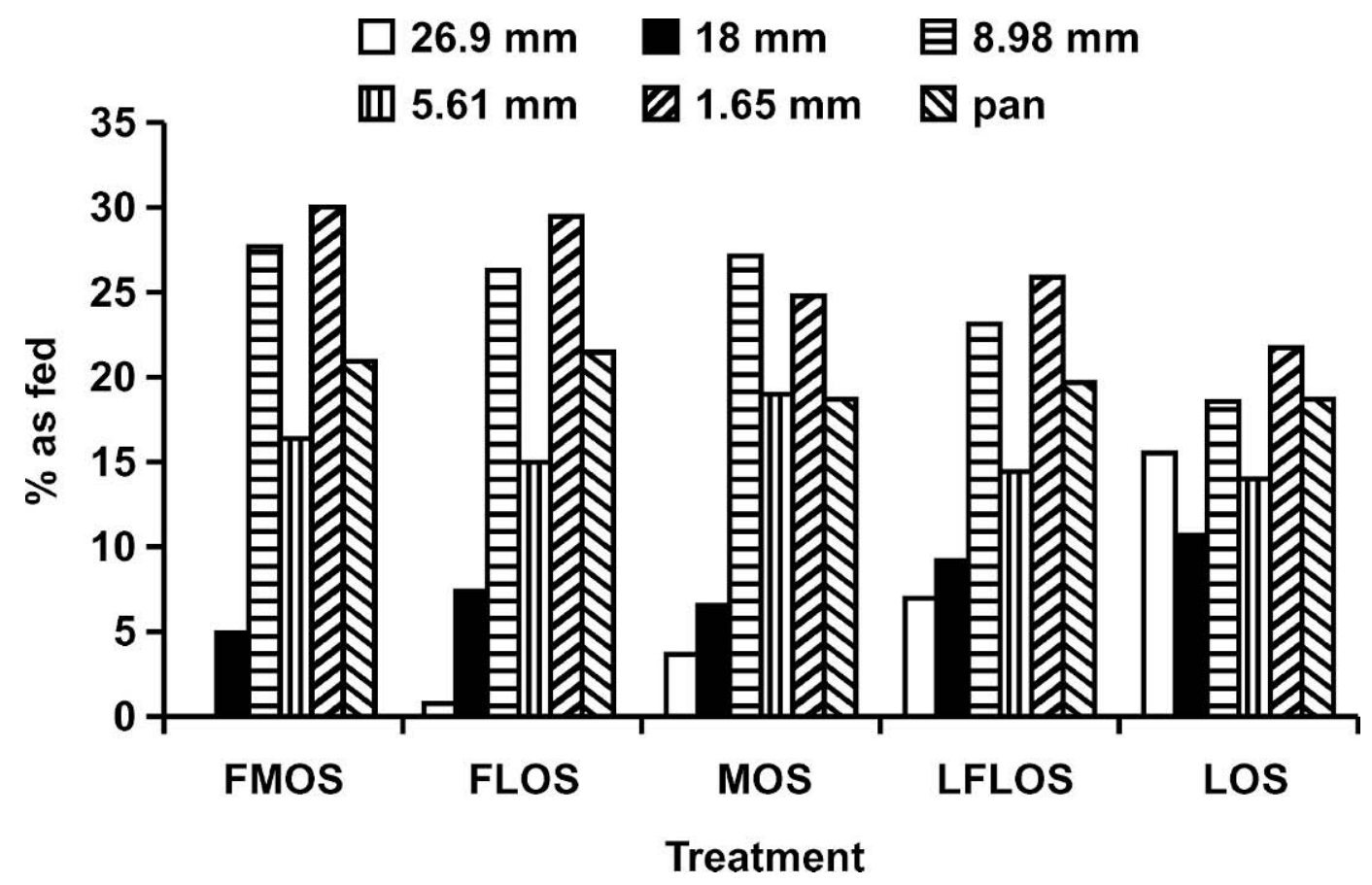

Figure 1. Dietary particles retained on each screen (as-fed basis). Screens are labeled from left (long material) to right (fine material) as $26.9,18,8.98,5.61$, and $1.65 \mathrm{~mm}$ and pan, respectively. Diets consisted of fine from medium oat silage (FMOS), fine from long oat silage (FLOS), medium oat silage (MOS), 50\% long oat silage and 50\% fine from long oat silage (LFLOS), and long oat silage (LOS). Standard deviations for $26.9,18,8.98,5.61$, and $1.65 \mathrm{~mm}$ and pan were $0.2,1.0,1.7,0.9,1.1$, and 1.7 for FMOS; 0.4, 1.3, 2.4, 1.0, 1.3, and 3.5 for FLOS; 1.9, 0.7, 1.3, 1.4, 0.9, and 1.7 for MOS; 1.4, 0.8, 1.5, 1.4, 1.1, and 2.5 for LFLOS; and 5.2, 1.7, 1.6, 1.3, 1.5, and 3.2 for LOS.

mined by microKjeldahl analysis (AOAC, 1990). Neutral detergent fiber was determined using $\alpha$-amylase (FAA, Ankom Technology, Fairport, NY), and sodium sulfite was corrected for ash concentration according to Van Soest et al. (1991), adapted for Ankom ${ }^{200}$ Fiber Analyzer (Ankom Technology). Acid detergent fiber was determined using the method described by Goering and Van Soest (1970), adapted for Ankom ${ }^{200}$ Fiber Analyzer (Ankom Technology) and corrected for ash concentration. Fatty acids were determined by following the procedure described by Sukhija and Palmquist (1988) and represented the sum of $\mathrm{C}_{14}$ to $\mathrm{C}_{18}$. The NFC component was calculated as $100-(\mathrm{NDF}+$ ether extract $+\mathrm{CP}+\mathrm{ash}$ ), where ether extract was calculated as fatty acid plus one (NRC, 2001). Reported NFC values are not corrected for NDF-CP or NPN.

\section{Sampling}

Cows were milked twice daily. Milk production was recorded, and milk was sampled at each milking during the last $5 \mathrm{~d}$ of each period. Milk samples were analyzed for protein and fat by infrared analysis (AgSource Milk Analysis Laboratory, Menomonie, WI) with a Fossmatic-605 (Foss Electric, Hillerød, Denmark) according to AOAC (1990).
On d 19 and 20 of each period, rumen fluid from cows in square MF was collected for $24 \mathrm{~h}$, every 4 $\mathrm{h}$, starting immediately before feeding. Samples were taken from 4 different locations in the rumen with a metal filter probe. Rumen $\mathrm{pH}$ was determined immediately after the sample was collected (Twin $\mathrm{pH}$-meter model B-123; Spectrum Technologies Inc., Plainfield, IL). One milliliter of rumen fluid was mixed with 20 $\mu \mathrm{L}$ of $50 \%$ trichloroacetic acid and frozen until analysis for $\mathrm{NH}_{3}$ (Chaney and Marbach, 1962). Another milliliter of rumen fluid was acidified with $20 \mu \mathrm{L}$ of $50 \%$ $\mathrm{H}_{2} \mathrm{SO}_{4}$ and frozen until analysis for VFA as described by Bal et al. (2000).

On d 19 of each period, 6 sets of 4 Dacron polyester bags $(9 \times 15 \mathrm{~cm} ; 52 \pm 5 \mu \mathrm{m}$ pore size $)$ were incubated for $24 \mathrm{~h}$ in each cow of square $\mathrm{MF}$ to determine ruminal in situ DM and NDF disappearance of unground soybean hulls. To account for possible effects of initial ruminal $\mathrm{pH}$ on NDF degradability, the starting time of each set was staggered every $4 \mathrm{~h}$, with the first set being incubated right before feeding. Bags containing $5 \pm 0.25 \mathrm{~g}$ of DM were soaked in warm water for $5 \mathrm{~min}$ before incubation, placed in a nylon laundry bag, and inserted in the ventral sac of the rumen. After incubation, bags were rinsed immediately in cold water and washed in a commercial washing machine for one cycle 
of $15 \mathrm{~min}$. Bags were dried in a forced-air oven at $60^{\circ} \mathrm{C}$ for $48 \mathrm{~h}$ to determine DM disappearance. Residues from quadruplicate bags were composited and analyzed for NDF.

Feeding behavior was monitored visually for $24 \mathrm{~h}$ during the last day of each experimental period. Cows were monitored during the exercise period but were not observed during milking time. Individual cow's eating and ruminating activities were recorded every $5 \mathrm{~min}$. It was assumed that each activity persisted for the entire 5-min interval. Chewing time represented the sum of the time spent eating and ruminating. The time spent eating, ruminating, and chewing expressed per $\mathrm{kg}$ of DMI was calculated utilizing the average DMI measured during the last $5 \mathrm{~d}$ of each experimental period.

Liquid and Cr-mordanted straw passage rates were estimated for 2 squares of cows (MF and square of multiparous cows with lowest milk production). Lithium-Co-EDTA and Cr-mordanted fiber were prepared as described by Udén et al. (1980). Chromium-mordanted fiber was prepared utilizing wheat straw NDF ground through a 6-mm screen (Wiley Mill; Arthur H, Thomas). In 2 nonruminally fistulated cows, lithiumCo-EDTA was orally bolused, and Cr-mordanted fiber was fed. It was not possible to bolus Cr-mordanted fiber because of the excessive volume. Chromium-mordanted fiber was top-dressed on the fresh diet as soon as the cows were fed. Ingestion within 2 min was confirmed visually, and there did not appear to be any residual marked straw. In the remaining 8 cows, markers were placed into the rumen through the rumen fistula at morning feeding and not mixed with the rumen content. Fecal grab samples were collected at $0,6,12,18,24,36,48,60,72$, and $96 \mathrm{~h}$ after dosing to determine solid and liquid rate of passage. Samples were dried, and fecal marker concentrations of $\mathrm{Cr}$ and Co were determined by direct current plasma emission spectroscopy (Spectra Metrics, Inc., subsidiary of Beckman Instruments, Inc., Andover, MA), as described by Combs and Satter (1992).

\section{Calculations and Statistical Analysis}

Sorting was calculated as the actual intake of each screen expressed as a percentage of the predicted intake. Predicted intake for an individual screen was calculated as the as-fed intake for the total diet multiplied by the as-fed fraction of that screen in the diet offered. Values equal to $100 \%$ indicate no sorting, $<100 \%$ show selective refusals, and $>100 \%$ indicate preferential consumption.

Data were analyzed using the mixed procedure of SAS (1998). Four individual degree of freedom con- trasts were made. Polynomial effects of GMPL were tested (linear and quadratic). Contrast coefficients were calculated utilizing the average GMPL of diets consumed (cGMPL) and not dGMPL. The cGMPL values used to calculate contrast coefficients were treatment means $(n=5)$. Contrasts were built to test for the effect of different PSD (MOS vs. LFLOS) and to test for differences between FMOS and FLOS. Diets FMOS and FLOS had similar dGMPL; therefore, differences between these 2 diets would indicate unequal silage fermentation caused by ensiling forage with different particle length. This comparison allowed us to discern whether differences caused by either GMPL or PSD were direct effects of particle length and distribution on the cows or if these effects were confounded by an indirect effect caused by different silage fermentation patterns.

Daily DMI, milk production, milk composition, chewing activities $(n=60)$, and Cr-mordanted straw and liquid rates of passage $(\mathrm{n}=30)$ were analyzed, with the final model including square, period, and treatment as fixed effects and cow within square as a random effect. The interactions square $\times$ treatment, period $\times$ treatment, and square $\times$ period were not significant $(P>0.25)$ and thus were not included in the final model.

Sorting $(\mathrm{n}=116)$ was analyzed by day as repeated measurements, utilizing a first-order auto regressive covariance structure. The final model included square, period, day, treatment, treatment $\times$ day, square $\times$ treatment, period $\times$ treatment, and square $\times$ period as fixed effects. Terms specified for the random statement were cow within square and treatment $\times$ period $\times$ cow within square.

Ruminal $\mathrm{pH}, \mathrm{VFA}$, and $\mathrm{NH}_{3}(\mathrm{n}=175)$ were analyzed by day and hour as repeated measurements, utilizing a first-order auto regressive covariance structure for hour and compound symmetry for day. The final model included period, day, hour, treatment, and hour $\times$ treatment as fixed effects. The interactions treatment $\times$ day and day $\times$ hour were not significant $(P>0.25)$ and thus were not included in the final model. Terms specified for the random statement were cow, treatment $\times$ period $\times$ cow, and day $\times$ treatment $\times$ period $\times$ cow.

Dry matter and NDF degradability of in situ bags ( $\mathrm{n}=85$ ) were analyzed by hour as repeated measurements, utilizing a first-order auto regressive covariance structure. The final model included period, hour, and treatment as fixed effects. The interaction of treatment $\times$ hour was not significant $(P>0.25)$ and thus was not included in the final model. Terms specified for the random statement were cow and treatment $\times$ period $\times$ cow. All covariance structures just listed 
provided the model with the best fit according to the Schwarz Bayesian criterion. Values reported are least squares means. Significance was declared at $P \leq 0.05$, and a trend was reported if $0.05<P \leq 0.10$.

When cGMPL had a significant linear effect on the response variable, regression equations were determined utilizing Proc REG (SAS Inst., Inc., Cary, NC). Equations were obtained regressing least squares means of dependent variables against cGMPL treatment means $(\mathrm{n}=5)$.

To verify the effect of sorting on the capability of GMPL to predict animal response, the linear effect of dGMPL or cGMPL was tested on dependent variables. Data were analyzed utilizing the mixed procedure of SAS (1998). The dependent variables considered were DMI, milk production, milk protein yield, and time spent eating and ruminating both as $\mathrm{min} / \mathrm{d}$ and $\mathrm{min} /$ $\mathrm{kg}$ of DMI. The model included period, square, either dGMPL or cGMPL ( $\mathrm{df}=1$ ), and cow within square as a random variable. The statistical models were the same for cGMPL vs. dGMPL except for the inclusion of either term. Therefore, to determine which model better explained the dependent variables variance, fit statistics (Akaike's information criterion), residual estimate, and significance of dGMPL and cGMPL were compared.

\section{RESULTS AND DISCUSSION}

One objective of this experiment was to differentiate the physical effect of feeding diets with different GMPL from a combination of physical and chemical effects. Differences between FMOS and FLOS would indicate that medium and LOS fermented differently. Very small but statistically significant differences were detected between FMOS and FLOS for sorting of $18-\mathrm{mm}(P=0.02)$ and $8.98-\mathrm{mm}(P=0.004)$ screens. Cows fed FLOS ate $98.1 \%$ of the offered particles retained on 18-mm screen, and $98.6 \%$ of the offered particles retained on 8.98-mm screen; conversely, cows fed FMOS ate $101.3 \%$ of the offered particles retained on $18-\mathrm{mm}$ screen and $100.7 \%$ of the offered particles retained on 8.98-mm screen (Table 3 and Figure 2). No other significant differences between FMOS and FLOS were detected. Therefore, it was concluded that changes caused by GMPL and PDS are uniquely due to physical characteristics and not different chemical characteristics attributable to altered silage fermentation.

\section{Forage and Diet Characteristics}

Long and MOS had similar chemical compositions (Table 2). Both oat silages were wetter than expected.
Table 3. Effect of different geometric mean particle length (GMPL), particle size distribution (PSD), and silo on sorting activity.

\begin{tabular}{|c|c|c|c|c|c|c|}
\hline \multirow{2}{*}{$\begin{array}{l}\text { Statistical } \\
\text { contrast }^{1}\end{array}$} & \multicolumn{6}{|c|}{ Square hole diagonal opening, mm } \\
\hline & 26.9 & 18 & 8.98 & 5.61 & 1.65 & Pan \\
\hline & & & & $(P)$ & & \\
\hline \multicolumn{7}{|l|}{ GMPL } \\
\hline Linear & 0.10 & 0.0002 & 0.10 & 0.0007 & $<0.0001$ & $<0.0001$ \\
\hline Quadratic & 0.98 & 0.17 & 0.09 & 0.85 & 0.20 & 0.30 \\
\hline PSD & 0.19 & 0.39 & 0.12 & 0.001 & 0.27 & 0.50 \\
\hline Silo & 0.23 & 0.02 & 0.004 & 0.93 & 0.23 & 0.68 \\
\hline
\end{tabular}

${ }^{1}$ Statistical contrast: linear and quadratic effects of different GMPL; effect of different PSD but similar GMPL (MOS vs. LFLOS = medium oat silage vs. 50\% long oat silage and 50\% fine from long oat silage); effect of silo fermentation characteristics but similar GMPL (FMOS vs. FLOS = fine from medium oat silage vs. fine from long oat silage).

Long oat silage was slightly dryer and was 1.6 percentage units lower in NDF than MOS. Therefore, FLOS, LFLOS, and LOS had a slightly lower NDF concentration compared with FMOS and MOS (Table 2).

As expected, LOS had more material retained on 26.9- and 18-mm screens than the remaining diets (Figure 1). Diet LFLOS was a mixture of equal parts of FLOS and LOS; therefore, LFLOS had more material retained on 26.9-, 18-, and 1.65-mm screens and in the pan but less material retained on 8.98- and 5.61-mm screens than MOS (Figure 1). Consequently, MOS and LFLOS had different PSD, but similar dGMPL (5.19 vs. $5.39 \mathrm{~mm}$, respectively), as intended. Also, FMOS and FLOS had similar dGMPL ( 4.35 vs. $4.46 \mathrm{~mm}$, respectively). The cGMPL was $6.25,5.05,4.39,4.32$, and $5.18 \mathrm{~mm}$ for LOS, MOS, FLOS, FMOS, and LFLOS, respectively.

\section{Intakes and Sorting}

Increasing cGMPL linearly decreased DMI $(P=$ 0.002 , Table 4) and NDF intake (NDFI, $P=0.002$ ). Cows decreased DMI by $0.9 \mathrm{~kg} / \mathrm{d}$ for each $1-\mathrm{mm}$ increment in cGMPL. Various studies have been conducted testing the effect of different forage lengths on DMI. The results to this point have been contradictory. Krause et al. (2002a) and some earlier studies (Shaver et al., 1986; Woodford et al., 1986) reported no significant effect of forage particle size on DMI. Fisher et al. (1994) found that increasing alfalfa silage mean particle length from 3.02 to $9.57 \mathrm{~mm}$ decreased DMI of multiparous cows by $1.1 \mathrm{~kg} / \mathrm{d}$. Mooney and Allen (1997) also reported decreased DMI of $1.7 \mathrm{~kg} / \mathrm{d}$ by feeding alfalfa silage with increasing mean particle size (5.8 vs. $11.4 \mathrm{~mm}$ ) for diets containing whole, linted cottonseed.

Dietary characteristics such as NDF and starch concentrations and starch fermentability may affect ani- 


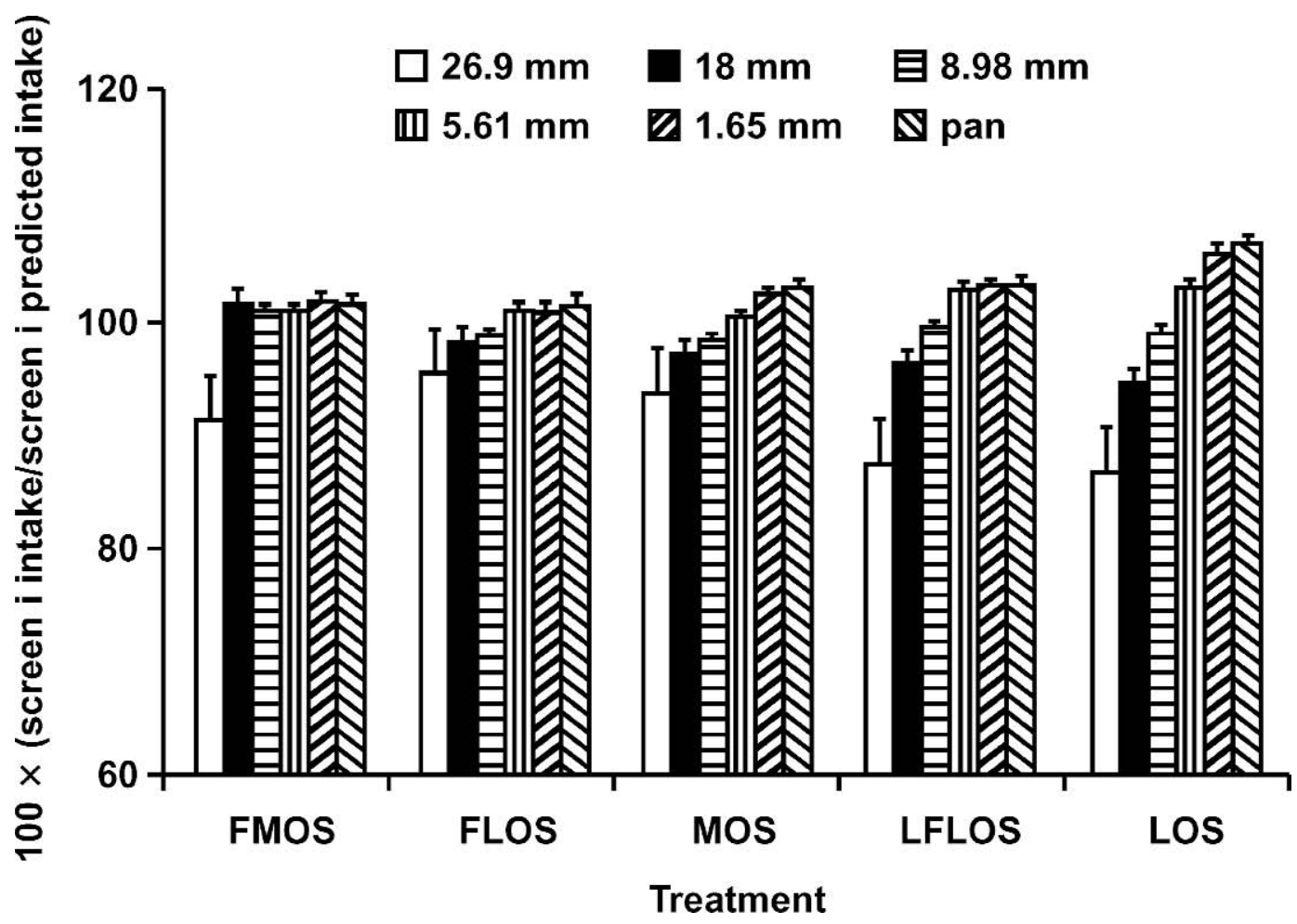

Figure 2. Least squares means for sorting activity $[100 \times($ screen i intake/screen i predicted intake)] (as-fed basis) of cows fed diets containing forages with different geometric mean particle length, different particle size distribution, and from different silo. Diets consisted of fine from medium oat silage (FMOS), fine from long oat silage (FLOS), medium oat silage (MOS), 50\% long oat silage and 50\% fine from long oat silage (LFLOS), and long oat silage (LOS). Screens are labeled from left (long material) to right (fine material) as 26.9, 18, 8.98, 5.61 , and $1.65 \mathrm{~mm}$ and pan, respectively.

mal response to feeding different dietary particle length and may explain the variability across experiments. Krause and Combs (2003) tested this hypothesis by feeding diets with different GMPL at 2 dietary starch concentrations and utilizing starch sources with different fermentability. Dietary NDF concentration was kept relatively constant across diets. Increasing dietary GMPL from 2.6 to $3.8 \mathrm{~mm}$ consistently increased DMI at various starch levels and starch fermentabilities, and no significant interactions were de-

Table 4. Effect of different geometric mean particle length (GMPL), particle size distribution (PSD), and silo on DMI, NDF intake (NDFI), milk yield, and milk composition.

\begin{tabular}{|c|c|c|c|c|c|c|c|c|c|c|}
\hline & \multicolumn{5}{|c|}{$\operatorname{Diet}^{1}$} & \multirow[b]{2}{*}{ SEM } & \multicolumn{4}{|c|}{ Statistical contrast $(P)^{2}$} \\
\hline & FMOS & FLOS & MOS & LFLOS & LOS & & Linear & Quadratic & PSD & Silo \\
\hline & & & & & & & & $(P)$ & & 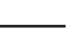 \\
\hline DMI, kg/d & 22.1 & 22.0 & 21.7 & 21.1 & 20.4 & 0.5 & 0.002 & 0.97 & 0.30 & 0.92 \\
\hline NDFI & 5.7 & 5.5 & 5.4 & 5.3 & 5.1 & 0.2 & 0.002 & 0.56 & 0.43 & 0.31 \\
\hline Milk yield, $\mathrm{kg} / \mathrm{d}$ & 39.6 & 40.2 & 38.8 & 38.9 & 38.2 & 1.0 & 0.004 & 0.45 & 0.80 & 0.34 \\
\hline \multicolumn{11}{|c|}{ Milk composition, \% } \\
\hline True protein & 2.73 & 2.71 & 2.73 & 2.71 & 2.69 & 0.05 & 0.14 & 0.51 & 0.51 & 0.49 \\
\hline Fat & 3.27 & 3.36 & 3.42 & 3.23 & 3.41 & 0.11 & 0.31 & 0.69 & 0.05 & 0.37 \\
\hline \multicolumn{11}{|c|}{ Milk component yield, $\mathrm{g} / \mathrm{d}$} \\
\hline True protein & 1074 & 1085 & 1052 & 1051 & 1021 & 27 & 0.002 & 0.79 & 0.95 & 0.58 \\
\hline Fat & 1287 & 1344 & 1318 & 1250 & 1280 & 42 & 0.19 & 0.49 & 0.05 & 0.11 \\
\hline
\end{tabular}

${ }^{1}$ FMOS = Fine from medium oat silage, FLOS = fine from long oat silage, MOS = medium oat silage, LFLOS = 50\% long oat silage and $50 \%$ fine from long oat silage, and LOS = long oat silage.

${ }^{2}$ Statistical contrast: linear and quadratic effects of different GMPL; effect of different PSD but similar GMPL (MOS vs. LFLOS); effect of silo fermentation characteristics but similar GMPL (FMOS vs. FLOS). 


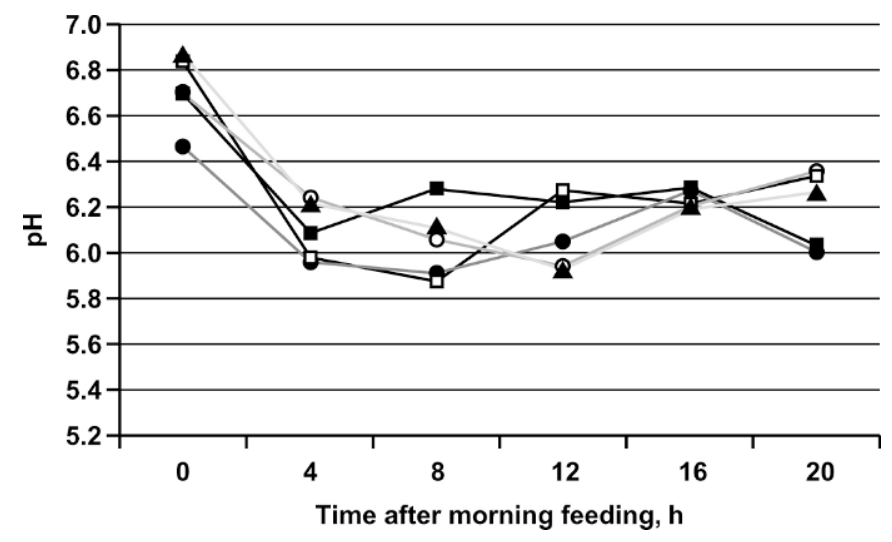

Figure 3. Effect of different geometric mean particle length, particle size distribution, and silo on ruminal $\mathrm{pH}$ diurnal fluctuations. Diets consisted of fine from medium oat silage [FMOS $(\bullet)$ ], fine from long oat silage [FLOS $(\bigcirc)$ ], medium oat silage [MOS (ם)], 50\% long oat silage and $50 \%$ fine from long oat silage [LFLOS $(\square)$ ], and long oat silage $[\operatorname{LOS}(\mathbf{\Lambda})]$. Pooled SEM $=0.13$. Significant treatment $\times$ time interaction $(P=0.04)$.

tected (Krause and Combs, 2003). One difference between Krause and Combs (2003), where increasing GMPL increased DMI, and Krause et al. (2002a and b), where no differences in DMI were observed, was time ruminal $\mathrm{pH}$ below 5.8. In Krause and Combs (2003) starch intake was higher, and consequently time ruminal $\mathrm{pH}<5.8$ was greater than in Krause et al. $(2002 \mathrm{a}, \mathrm{b})$; as suggested by the authors, this could increase the likelihood of a negative effect of decreasing forage particle size. In the present experiment, dGMPL range (3.35 to $6.68 \mathrm{~mm}$ ) and rumen $\mathrm{pH}$ were greater than Krause and Combs (2003) and Krause et al. (2002a and b), and rumen $\mathrm{pH}$ was never $<5.8$ (Figure 3). Therefore, it appears that at a lower rumen $\mathrm{pH}$, long dietary particles can have a positive effect on DMI, whereas at a higher rumen $\mathrm{pH}$, long dietary particles may reduce DMI.

Increasing cGMPL linearly decreased NDFI $(P=$ 0.002 ). This was mainly a result of a lower DMI. However, not all of the decrease in NDFI could be explained by the decrease in DMI. In fact, when DMI was introduced into the model as a covariate, the linear effect of cGMPL on NDFI was still significant $(P=0.03$; data not shown). The residual linear effect of cGMPL on NDFI could be explained by variation in sorting across diets (Figure 2; Table 3). Feeding diets with increasing GMPL tended to linearly increase sorting against long particles $(26.9-\mathrm{mm}$ screen, $P=0.10)$ in favor of smaller particles $(1.65-\mathrm{mm}$ screen and pan, $P<0.001)$. Similarly, Leonardi and Armentano (2003) reported that cows generally tend to sort against longer particles in favor of smaller particles. However, in the present experiment, the extent of sorting was smaller, proba- bly because $50 \%$ of dietary DM consisted of silage, whereas in Leonardi and Armentano (2003) the maximum amount of silage fed was $20 \%$ of the diet (DM basis). Diets containing only alfalfa hay (40\% of dietary DM) as a forage source were more prone to be sorted than diets containing a mixture of alfalfa hay and silage (Leonardi and Armentano, 2003). Sorting affected the NDF concentration of the diet ingested. The NDF concentration of the diet offered was $26.2 \%$ for FMOS and MOS and $25.8 \%$ for FLOS, LFLOS, and LOS. The NDF concentration of the diet ingested 100 $\times(\mathrm{NDFI} / \mathrm{DMI})$ was $25.6 \%$ for FMOS, $25.0 \%$ for FLOS, $24.9 \%$ for MOS, $24.9 \%$ for LFLOS, and $24.7 \%$ for LOS.

There was a significant square $\times$ treatment interaction on sorting of 5.61-mm screen $(P=0.05)$ and of $1.65-\mathrm{mm}$ screen $(P=0.006)$. When fed MOS, LFLOS, and LOS, primiparous cows sorted to a higher extent in favor of particles retained on 1.65-mm screen than did multiparous cows (data not shown). When fed LFLOS, primiparous cows sorted to a higher extent in favor of particles retained on 5.61-mm screen than did multiparous cows (data not shown). Furthermore, square had a significant effect on sorting of particles retained on $26.9-\mathrm{mm}$ screen $(P=0.04), 18-\mathrm{mm}$ screen $(P=0.02), 8.98-\mathrm{mm}$ screen $(P=0.02)$, and $1.65-\mathrm{mm}$ screen $(P<0.001)$. The difference among squares was attributable mainly to primiparous cows sorting more against longer particles (26.9-, 18-, and 8.98-mm screens) and more in favor of shorter particles (1.65$\mathrm{mm}$ screen) than multiparous cows. Although a statistical comparison was not made, sorting activity across the 3 squares containing only multiparous cows was similar. Intake of particles retained on 26.9-mm screen expressed as a percentage of offered was $80 \%$ for primiparous and $94.4 \%$ for multiparous cows. Intake of particles retained on 18- $\mathrm{mm}$ screen expressed as a percentage of offered was $94.7 \%$ for primiparous and 98.4\% for multiparous cows. Intake of particles retained on 8.98-mm screen expressed as a percentage of offered was $98.1 \%$ for primiparous and $99.6 \%$ for multiparous cows. Intake of particles retained on 1.65mm screen expressed as a percentage of offered was $104.5 \%$ for primiparous and $102.4 \%$ for multiparous cows. In a previously conducted experiment, sorting activity was not significantly different between primiparous and multiparous cows (Leonardi and Armentano, 2003). Furthermore, treatment effect did not vary between parities (Leonardi and Armentano, 2003). In Leonardi and Armentano (2003), diets contained either only alfalfa hay or a mixture of alfalfa silage and hay. Conversely, in the present experiment, a mixture of corn silage and oat silage was fed. It is possible that the different type of forages fed could 
Table 5. Effect of different geometric mean particle length (GMPL), particle size distribution (PSD), and silo on feeding behavior.

\begin{tabular}{|c|c|c|c|c|c|c|c|c|c|c|}
\hline \multirow[b]{2}{*}{ Item } & \multicolumn{5}{|c|}{$\operatorname{Diet}^{1}$} & \multirow[b]{2}{*}{ SEM } & \multicolumn{4}{|c|}{ Statistical contrast $(P)^{2}$} \\
\hline & FMOS & FLOS & MOS & LFLOS & LOS & & Linear & Quadratic & PSD & Silo \\
\hline & & & $(\min / \mathrm{d})$ & & & & & $(P)$ & & \\
\hline Eating & 229 & 236 & 242 & 262 & 267 & 14 & 0.02 & 0.59 & 0.24 & 0.66 \\
\hline Ruminating & 529 & 530 & 539 & 542 & 549 & 14 & 0.12 & 0.78 & 0.60 & 0.99 \\
\hline \multirow[t]{2}{*}{ Chewing } & 758 & 766 & 779 & 807 & 817 & 20 & 0.003 & 0.49 & 0.17 & 0.68 \\
\hline & & - (mi & $\mathrm{l} / \mathrm{kg}$ of I & MI) - & & & & & & \\
\hline Eating & 10.6 & 11.0 & 11.2 & 12.7 & 13.4 & 0.7 & 0.001 & 0.79 & 0.09 & 0.60 \\
\hline Ruminating & 24.9 & 24.7 & 25.7 & 26.5 & 28.0 & 0.9 & 0.0002 & 0.96 & 0.38 & 0.84 \\
\hline Chewing & 35.3 & 35.7 & 36.8 & 39.3 & 41.5 & 1.2 & $<0.0001$ & 0.85 & 0.08 & 0.79 \\
\hline
\end{tabular}

${ }^{1} \mathrm{FMOS}=$ Fine from medium oat silage, $\mathrm{FLOS}=$ fine from long oat silage, $\mathrm{MOS}=$ medium oat silage, LFLOS $=50 \%$ long oat silage and 50\% fine from long oat silage, and LOS = long oat silage.

${ }^{2}$ Statistical contrast: linear and quadratic effects of different GMPL; effect of different PSD but similar GMPL (MOS vs. LFLOS); effect of silo fermentation characteristics but similar GMPL (FMOS vs. FLOS).

account for the different parities effect in the 2 experiments.

In the present experiment, we also wanted to determine whether sorting would change across time (d 7 vs. 21) or if there was any day $\times$ treatment interaction. There was no significant day $\times$ treatment interaction on sorting of any of the screens. There was a small but statistically significant day effect on sorting of 8.98 -mm screen $(P=0.001)$, which was $99.8 \%$ on d 7 and $98.6 \%$ on $\mathrm{d} 21$.

\section{Milk Production and Milk Composition}

Increasing cGMPL linearly decreased milk production $(P=0.004)$ and true protein yield $(P=0.003)$ (Table 4). Cows decreased milk production by $0.91 \mathrm{~kg} /$ $\mathrm{d}$ and protein yield by $31 \mathrm{~g} / \mathrm{d}$ for each $1-\mathrm{mm}$ increment in cGMPL. The decreased milk production and true protein yield was probably due to a lower energy intake, related to a lower DMI. When the actual dietary DMI was used in the NRC (2001) program to estimate theoretical milk production differences between diets, the difference between LOS and the average of the 2 finest diets (FMOS and FLOS) was predicted to be 3.4 $\mathrm{kg} / \mathrm{d}$. The difference detected in the present experiment was $1.1 \mathrm{~kg} / \mathrm{d}$. Therefore, some other factors might have been affecting milk production. One possible explanation is that cows fed LOS sorted in favor of smaller particles, which consisted mainly of grain; therefore, they ingested a diet with a higher energy content than the one offered. Concurrently, increased cGMPL could have resulted in increased retention time and increased total tract digestibility, therefore partially compensating for the lower DMI. Dry matter intake significantly affected true protein yield $(P=$ 0.002; data not shown), and the linear effect of GMPL became a trend $(P=0.10$; data not shown) after the introduction of DMI into the model as a covariate. The decreased milk true protein yield was probably the result of the lower DMI. There were no significant linear or quadratic effects of cGMPL on fat and true protein percentage or fat yield.

Particle size distribution had a significant effect on milk composition. Feeding a mixture of long and finely chopped oat silage (LFLOS) reduced milk fat percentage $(P=0.05)$ and yield $(P=0.05)$ compared with medium chopped oat silage. It is not clear why cows fed MOS produced more milk fat than cows fed LFLOS. Numerically, cows fed FMOS produced less milk fat than cows fed FLOS; thus the difference caused by PDS does not appear to be related to different silage fermentation. Therefore, contrary to our hypothesis, other factors, such as PSD, affected some of the variables measured.

\section{Chewing Activities}

The overall time spent eating ranged from 3.8 to 4.5 $\mathrm{h} / \mathrm{d}$, and time spent ruminating ranged from 8.8 to 9.2 $\mathrm{h} / \mathrm{d}$ (Table 5). The time spent eating and ruminating the 2 finer diets (FMOS and FLOS) was similar to that reported for the coarser diets fed in Krause and Combs (2003), which had a GMPL similar to FMOS and FLOS. Beauchemin et al. (1994) reported that healthy highproducing cows should ruminate $>6 \mathrm{~h} / \mathrm{d}$. Sudweeks et al. (1981) also suggested that to limit the risk of digestive disorders, cows should chew at least $30 \mathrm{~min} / \mathrm{kg}$ of DMI. In the present study, cows' chewing activity ranged from 35.3 to $41.5 \mathrm{~min} / \mathrm{kg}$ of DMI. Time spent chewing per $\mathrm{kg}$ of DMI and overall time ruminating suggest that animals in the present study were not prone to digestive disorders.

Total time spent eating $(P=0.02)$ and chewing $(P=$ 0.003 ) increased linearly with increasing cGMPL. 
Table 6. Effect of different geometric mean particle length (GMPL), particle size distribution (PSD), and silo on ruminal $\mathrm{pH}, \mathrm{NH}_{3}$, and VFA.

\begin{tabular}{|c|c|c|c|c|c|c|c|c|c|c|}
\hline \multirow[b]{2}{*}{ Item } & \multicolumn{5}{|c|}{$\operatorname{Diet}^{1}$} & \multirow[b]{2}{*}{ SEM } & \multicolumn{4}{|c|}{ Statistical contrast $^{2}$} \\
\hline & FMOS & FLOS & MOS & LFLOS & LOS & & Linear & Quadratic & PSD & Silo \\
\hline & & & & & & & & $-(P)$ & & \\
\hline $\mathrm{pH}$ & 6.11 & 6.25 & 6.27 & 6.26 & 6.27 & 0.08 & 0.28 & 0.40 & 0.87 & 0.16 \\
\hline $\mathrm{NH}_{3}, \mathrm{mg} / \mathrm{dL}$ & 11.9 & 11.8 & 10.0 & 12.0 & 9.9 & 0.8 & 0.11 & 0.98 & 0.12 & 0.93 \\
\hline \multirow[t]{2}{*}{ VFA, mM } & 106.7 & 100.0 & 96.7 & 100.8 & 100.3 & 4.3 & 0.55 & 0.41 & 0.55 & 0.34 \\
\hline & & - $(\mathrm{r}$ & $01 / 100 n$ & ol) & & & & & & \\
\hline Acetate (A) & 57.6 & 56.1 & 59.1 & 55.3 & 59.1 & 1.5 & 0.33 & 0.63 & 0.12 & 0.49 \\
\hline Propionate (P) & 24.9 & 28.0 & 26.7 & 28.2 & 24.7 & 1.8 & 0.54 & 0.31 & 0.55 & 0.27 \\
\hline Butyrate & 12.6 & 12.0 & 11.5 & 11.3 & 11.5 & 0.6 & 0.21 & 0.29 & 0.75 & 0.39 \\
\hline $\mathrm{A}: \mathrm{P}$ & 2.41 & 2.04 & 2.35 & 2.02 & 2.64 & 0.27 & 0.33 & 0.42 & 0.45 & 0.39 \\
\hline
\end{tabular}

${ }^{1}$ FMOS $=$ Fine from medium oat silage, $\mathrm{FLOS}=$ fine from long oat silage, $\mathrm{MOS}=$ medium oat silage, LFLOS $=50 \%$ long oat silage and 50\% fine from long oat silage, and LOS = long oat silage.

${ }^{2}$ Statistical contrast: linear and quadratic effects of different GMPL; effect of different PSD but similar GMPL (MOS vs. LFLOS); effect of silo fermentation characteristics but similar GMPL (FMOS vs. FLOS).

Cows increased time spent eating by $19.1 \mathrm{~min} / \mathrm{d}$ and time spent ruminating by $10.5 \mathrm{~min} / \mathrm{d}$ for each $1-\mathrm{mm}$ increment in cGMPL. The increased time spent eating and chewing was a result of an increased time spent eating and chewing per $\mathrm{kg}$ of DMI. Time spent ruminating per kg of DMI also increased linearly, increasing cGMPL. Cows increased time spent eating by 1.42 $\mathrm{min} / \mathrm{kg}$ of DMI and time spent ruminating by $1.70 \mathrm{~min} /$ $\mathrm{kg}$ of DMI for each 1-mm increment in cGMPL. It has been shown in various experiments that increasing GMPL increased time spent eating and ruminating per kilogram of DMI (Soita et al., 2000; Beauchemin et al., 2003; Krause and Combs, 2003). Cows fed MOS tended $(P=0.09)$ to spend less time eating per kilogram of DMI than cows fed LFLOS. We defined the action of eating as a mouth movement that does not include ruminating, drinking, or social exchanges; therefore, it includes activity such as moving feeds around in the manger, provided a jaw move is involved. It is possible that the increased total eating time and time spent eating per kilogram of DMI for LFLOS vs. MOS was due to cows spending more time sorting LFLOS than MOS.

In the present experiment, cumulative percentage on and above the $1.65-\mathrm{mm}$ screen was similar across treatments and was $79.0 \%$ for FMOS, $78.6 \%$ for FLOS, $81.3 \%$ for MOS, $80.2 \%$ for LFLOS, and $81.3 \%$ for LOS. However, the cumulative percentage on and above the $1.65-\mathrm{mm}$ screen was similar across treatment time spent ruminating per kilogram of DMI increased with increasing cGMPL, indicating that the dietary percentage retained on a sieve with a diagonal opening of $1.65 \mathrm{~mm}$ does not provide the best estimate of peNDF. Similarly, Kononoff and Heinrichs (2003) conducted a study in which they tested alfalfa silage with different GMPL but a similar fraction retained above a screen of
$1.18 \mathrm{~mm}$. Feeding diets with increasing GMPL linearly increased DMI and total chewing activity per kilogram of DMI (Kononoff and Heinrichs, 2003). Therefore, 2 recent experiments have showed that the percentage of the diet retained on a sieve with an aperture of 1.18 $\mathrm{mm}$ does not provide the best estimate of peNDF.

\section{Rumen Measurements}

There were no significant differences in rumen $\mathrm{pH}$, total VFA concentration, molar proportion of individual VFA, and $\mathrm{NH}_{3}$ between FMOS and FLOS or between MOS and LFLOS (Table 6). There was a treatment $\times$ time interaction for rumen $\mathrm{pH}$ (Figure 3 ). The interaction, however, is not clear; the major differences across diets seemed to be at 8 and $12 \mathrm{~h}$ after the morning feeding. Eight hours after feeding, the ruminal $\mathrm{pH}$ of cows fed MOS did not drop as much as that of cows fed the other diets, and it stayed stable after that. Mean ruminal $\mathrm{pH}$ was $>6$ for all dietary treatments (Table 6), and there was no significant linear or quadratic effect of cGMPL on mean ruminal $\mathrm{pH}$. Furthermore, there was also no significant linear or quadratic effect of cGMPL on total VFA concentration or molar proportion of the various volatile fatty acids. Krause et al. (2002b) reported an increase in mean ruminal $\mathrm{pH}$ with increasing forage particle length. Kononoff and Heinrichs (2003) reported that modifying dietary particle length through replacing short alfalfa haylage with long alfalfa haylage at different levels resulted in a quadratic increase in mean ruminal $\mathrm{pH}$. Various experiments reported that mean ruminal $\mathrm{pH}$ was not correlated to dietary mean particle length (Yang et al., 2001; Beauchemin et al., 2003).

In Krause et al. (2002b), overall average ruminal $\mathrm{pH}$ was 5.92 and was lower than the average $\mathrm{pH}$ ob- 
Table 7. Effect of different geometric mean particle length (GMPL), particle size distribution (PSD), and silo on in situ DM and NDF disappearance of soybean hulls after $24 \mathrm{~h}$ of incubation and ruminal $\mathrm{Cr}$ mordanted straw and liquid outflow rates.

\begin{tabular}{|c|c|c|c|c|c|c|c|c|c|c|}
\hline \multirow[b]{2}{*}{ Item } & \multicolumn{5}{|c|}{$\operatorname{Diet}^{1}$} & \multirow[b]{2}{*}{ SEM } & \multicolumn{4}{|c|}{ Statistical contrast ${ }^{2}$} \\
\hline & FMOS & FLOS & MOS & LFLOS & LOS & & Linear & Quadratic & PSD & Silo \\
\hline In situ disappearance & & & $(\%)$ & & - & & & $-(P)$ & 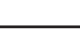 & \\
\hline $\mathrm{DM}$ & 73.0 & 75.0 & 74.5 & 74.4 & 74.4 & 2.7 & 0.88 & 0.88 & 0.98 & 0.57 \\
\hline $\mathrm{NDF}$ & 44.7 & 49.2 & 49.4 & 48.6 & 47.8 & 5.9 & 0.87 & 0.72 & 0.91 & 0.57 \\
\hline Rumen & & & $(\% / \mathrm{h})$ & & & & & & & \\
\hline Straw outflow rate ${ }^{3}$ & 4.1 & 4.0 & 4.6 & 3.9 & 4.5 & 0.2 & 0.10 & 0.92 & 0.03 & 0.48 \\
\hline Liquid outflow rate & 10.3 & 10.1 & 10.8 & 9.9 & 9.7 & 0.5 & 0.32 & 0.45 & 0.11 & 0.72 \\
\hline
\end{tabular}

${ }^{1}$ FMOS = Fine from medium oat silage, FLOS = fine from long oat silage, MOS = medium oat silage, LFLOS $=50 \%$ long oat silage and 50\% fine from long oat silage, and LOS = long oat silage.

${ }^{2}$ Statistical contrast: linear and quadratic effects of different GMPL; effect of different PSD but similar GMPL (MOS vs. LFLOS); effect of silo fermentation characteristics but similar GMPL (FMOS vs. FLOS).

${ }^{3}$ Straw outflow rate $=$ Cr-mordanted straw outflow rate.

served in the present experiment. In Krause et al. (2002b), the increased chewing activity resulted in increased average ruminal $\mathrm{pH}$, probably because of an increased saliva flow. Sodium bicarbonate, which is the major buffer in saliva, has a $\mathrm{pH}$ of 6.25. Therefore, saliva addition through increasing chewing activity at ruminal $\mathrm{pH}$ close to 6.25 should not increase ruminal $\mathrm{pH}$ to the same extent as at a ruminal $\mathrm{pH}<6.0$, probably explaining the difference between experiments.

Ruminal rate of passage of $\mathrm{Cr}$-mordanted straw and liquid phase were not affected by cGMPL (Table 7). Overall rates were similar to values reported by Krause et al. (2002a). Feeding LFLOS reduced Crmordanted straw rate of passage compared with feeding MOS $(P=0.03)$. Feeding either FLOS or LOS alone resulted in a faster $\mathrm{Cr}$-mordanted straw rate of pas- sage than feeding a mixture of the 2 (LFLOS); therefore, the slower Cr-mordanted straw rate of passage of LFLOS compared with MOS is not simply related to GMPL and appeared to be influenced by PSD. It seems that feeding the 2 together resulted in an interaction. There is no clear explanation for this difference; however, other variables measured support this effect.

Mourino et al. (2001) measured cellulose degradation in an in vitro system at various $\mathrm{pH}$ values. It was suggested that the initial $\mathrm{pH}$ of the incubation affected the rate at which cellulose was digested (Mourino et al., 2001). A model was proposed under which the adhesion of cellulolytic bacteria to fiber particles would decrease if initial $\mathrm{pH}$ was between 5.3 and 6.0 (Mourino et al., 2001). In the present experiment, bags were incubated every $4 \mathrm{~h}$ to have different initial $\mathrm{pH}$ and

Table 8. Linear effect of either dietary geometric mean particle length (dGMPL) or geometric mean particle length of diet consumed (cGMPL) on dependent variables where significant linear effect of GMPL was reported.

\begin{tabular}{|c|c|c|c|c|}
\hline \multirow[b]{2}{*}{ Dependent variable } & & \multicolumn{3}{|c|}{ Statistic $^{1}$} \\
\hline & & $P$ & $\mathrm{RE}$ & $\mathrm{AIC}$ \\
\hline \multirow[t]{2}{*}{ DMI, kg/d } & dGMPL & 0.0009 & 1.51 & 221 \\
\hline & cGMPL & 0.003 & 1.60 & 223 \\
\hline \multirow[t]{2}{*}{ Milk, kg/d } & dGMPL & 0.003 & 1.98 & 256 \\
\hline & cGMPL & 0.001 & 1.91 & 254 \\
\hline \multirow[t]{2}{*}{ Milk protein yield, g/d } & dGMPL & 0.0006 & 0.0019 & -109 \\
\hline & cGMPL & 0.0003 & 0.0019 & -111 \\
\hline \multirow[t]{2}{*}{ Eating, $\mathrm{min} / \mathrm{d}$} & dGMPL & 0.04 & 1518 & 569 \\
\hline & cGMPL & 0.13 & 1602 & 571 \\
\hline \multirow[t]{2}{*}{ Eating, $\mathrm{min} / \mathrm{kg}$ of DMI } & dGMPL & 0.002 & 4.31 & 260 \\
\hline & cGMPL & 0.02 & 4.81 & 263 \\
\hline \multirow[t]{2}{*}{ Ruminating, $\min / \mathrm{d}$} & dGMPL & 0.11 & 879 & 558 \\
\hline & cGMPL & 0.05 & 837 & 554 \\
\hline \multirow{2}{*}{ Ruminating, $\mathrm{min} / \mathrm{kg}$ of DMI } & dGMPL & $<0.0001$ & 3.63 & 270 \\
\hline & cGMPL & $<0.0001$ & 3.56 & 270 \\
\hline
\end{tabular}

\footnotetext{
${ }^{1}$ The model included period, square, cow within square, and the linear effect of either dGMPL or cGMPL. $P=$ linear effect of either dGMPL or cGMPL, RE = residual estimate, and AIC = Akaike's information criterion.
} 
verify the effect of initial $\mathrm{pH}$ on NDF degradability in an in vivo system. Time of incubation did not affect DM and NDF disappearance, and treatments did not differ across time. However, the within-treatment average initial $\mathrm{pH}$ was never $<5.9$. Therefore, the lack of time effect could be due to the initial rumen $\mathrm{pH}$ being borderline high in the range suggested by Mourinio et al. (2001). In situ DM and NDF disappearance of soybean hulls after $24 \mathrm{~h}$ of incubation were similar across treatments (Table 7). Batajoo and Shaver (1998) reported similar DM disappearance of soybean hulls after $24 \mathrm{~h}$ of incubation in the rumen; however, NDF disappearance was not measured.

\section{dGMPL vs. cGMPL}

Response variables that were measured on a cow can be categorized into 2 groups: variables affected by what the cow has been offered and variables affected by what the cow actually ate. The first group should probably include DMI and time spent eating as $\mathrm{min} /$ $\mathrm{d}$ and $\mathrm{min} / \mathrm{kg}$ of DMI, especially if eating time, as previously suggested, also included time spent sorting feed. Conversely, other variables such as milk production, milk protein yield, and time spent ruminating both as $\mathrm{min} / \mathrm{d}$ and $\mathrm{min} / \mathrm{kg}$ of DMI should be affected only by what the cow actually ate. Therefore, dGMPL should better explain DMI and time spent eating, whereas cGMPL should better explain the remaining variables. This was generally in agreement with the $P$ values and fit statistics reported in Table 8. Milk yield and time spent ruminating as $\mathrm{min} / \mathrm{d}$ were better explained by cGMPL than by dGMPL. Utilizing cGMPL vs. dGMPL in the model decreased the possibility of a nonsignificant effect of GMPL. The residual error and the Akaike's information criterion values decreased, indicating a better fit to the data for cGMPL than for dGMPL. Time spent eating both as min/d and $\mathrm{min} / \mathrm{kg}$ of DMI were better explained by dGMPL than by cGMPL. For time spent ruminating as $\mathrm{min} / \mathrm{kg}$ of DMI, the effect of either dGMPL or cGMPL was highly significant $(P<0.0001)$, the Akaike's information criterion values were the same, and residual error was slightly smaller for cGMPL than for dGMPL. Overall, the inclusion of sorting in GMPL better explained those dependent variables likely to be affected by what the cow actually consumed.

\section{CONCLUSIONS}

Dietary geometrical mean particle length appears to be a good predictor of animal response independent of the particle size distribution. Because particles longer than $26.9 \mathrm{~mm}$ may be selected against by some cows, to obtain a uniform response across the entire herd, it is better to achieve adequate mean particle length with the least amount of particles longer than $26.9 \mathrm{~mm}$ and the greatest amount of particles between 26.9 and $9 \mathrm{~mm}$.

\section{REFERENCES}

American National Standards Institute. 1998. Method of Determining and Expressing Particle Size of Chopped Forage Materials by Screening. Standards. Am. Soc. Agric. Eng., St. Joseph, MI.

American National Standards Institute. 2001. Method of Determining and Expressing Particle Size of Chopped Forage Materials by Sieving. Standards. Am. Soc. Agric. Eng., St. Joseph, MI.

Association of Official Analytical Chemists. 1990. Official Methods of Analysis. Vol. I. 15th ed. AOAC, Arlington, VA.

Bal, M. A., R. D. Shaver, A. G. Jirovec, K. J. Shinners, and J. G. Coors. 2000. Corn processing and chop length of corn silage: Effects on intake, digestion, and milk production by dairy cows. J. Dairy Sci. 83:1264-1273.

Batajoo, K. K., and R. D. Shaver. 1998. In situ dry matter, crude protein, and starch degradabilities of selected grains and byproduct feeds. Anim. Feed Sci. Technol. 71:165-176.

Beauchemin, K. A., B. I. Farr, L. M. Rode, and G. B. Schaalje. 1994. Effects of alfalfa silage chop length and supplementation of long hay on chewing activity and milk production of dairy cows. J. Dairy Sci. 77:1326-1339.

Beauchemin, K. A., W. Z. Yang, and L. M. Rode. 2003. Effects of particle size of alfalfa-based dairy cow diets on chewing activity, ruminal fermentation, and milk production. J. Dairy Sci. 86:630-643.

Chaney, A. L., and E. P. Marbach. 1962. Modified reagents for determination of urea and ammonia. Clin. Chem. 8:130-132.

Combs, D. K., and L. D. Satter. 1992. Determination of markers in digesta and feces by direct current plasma emission spectroscopy. J. Dairy Sci. 75:2176-2183.

Fisher, J. M., J. G. Buchanan-Smith, C. Campbell, D. G. Grieve, and O. B. Allen. 1994. Effects of forage particle size and long hay for cows fed total mixed rations based on alfalfa and corn. J. Dairy Sci. 77:217-229.

Goering, H. K., and P. J. Van Soest. 1970. Forage Fiber Analysis. (Apparatus, Reagents, Procedures, and some Applications). Agric. Handbook No. 379. ARS-USDA, Washington, DC.

Kononoff, P. J., and A. J. Heinrichs. 2003. The effect of reducing alfalfa haylage particle size on cows in early lactation. J. Dairy Sci. 86:1445-1457.

Krause, K. M., and D. K. Combs. 2003. Effects of forage particle size, forage source, and grain fermentability on performance and ruminal pH in midlactation cows. J. Dairy Sci. 86:1382-1397.

Krause, K. M., D. K. Combs, and K. A. Beauchemin. 2002a. Effects of forage particle size and grain fermentability in midlactation cows. I. Milk production and diet digestibility. J. Dairy Sci. 85:1936-1946.

Krause, K. M., D. K. Combs, and K. A. Beauchemin. 2002b. Effects of forage particle size and grain fermentability in midlactation cows. II. Ruminal $\mathrm{pH}$ and chewing activity. J. Dairy Sci. 85:1947-1957.

Leonardi, C., and L. E. Armentano. 2003. Effect of quantity, quality, and length of alfalfa hay on selective consumption by dairy cows. J. Dairy Sci. 86:557-564.

Mertens, D. R. 1997. Creating a system for meeting the fiber requirements of dairy cattle. J. Dairy Sci. 80:1463-1482.

Mooney, C. S., and M. S. Allen. 1997. Physical effectiveness of the neutral detergent fiber of whole linted cottonseed relative to that of alfalfa silage at two lengths of cut. J. Dairy Sci. 80:2052-2061. 
Mourino, F., R. Akkarawongsa, and P. J. Weimer. 2001. Initial pH as a determinant of cellulose digestion rate by mixed ruminal microorganisms in vitro. J. Dairy Sci. 84:848-859.

National Research Council. 2001. Nutrient Requirements of Dairy Cattle. 7th rev. ed. Natl. Acad. Sci., Washington, DC.

SAS User's Guide: Statistics. 7th Ed. 1998. SAS Inst., Inc., Cary, NC.

Shaver, R. D., A. J. Nytes, L. D. Satter, and N. A. Jorgensen. 1986. Influence of amount of feed intake and forage physical form on digestion and passage of prebloom alfalfa hay in dairy cows. J. Dairy Sci. 69:1545-1559.

Soita, H. W., D. A. Christensen, and J. J. McKinnon. 2000. Influence of particle size on the effectiveness of the fiber in barley silage J. Dairy Sci. 83:2295-2300.

Sudweeks, E. M., L. O. Ely, D. R. Mertens, and L. R. Sisk. 1981. Assessing the minimum amounts and form of roughages in ruminant diets: Roughage value index system. J. Anim. Sci. 53:1406-1411.
Sukhija, P. S., and D. L. Palmquist. 1988. Rapid method for determination of total fatty acid content and composition of feedstuffs and feces. J. Agric. Food Chem. 36:1202-1206.

Udén, P., P. E. Colucci, and P. J. Van Soest. 1980. Investigation of chromium, cerium, and cobalt as digesta flow markers in rate of passage studies. J. Sci. Food Agric. 31:625-632.

Van Soest, P. J., J. B. Robertson, and B. A. Lewis. 1991. Methods for dietary fiber, neutral detergent fiber, and nonstarch polysaccharides in relation to animal nutrition. J. Dairy Sci. 74:35833597.

Woodford, J. A., N. A. Jorgensen, and G. P. Barrington. 1986. Impact of dietary fiber and physical form on performance of lactating dairy cows. J. Dairy Sci. 69:1035-1047.

Yang, W. Z., K. A. Beauchemin, and L. M. Rode. 2001. Barley processing, forage concentrate, and forage length effects on chewing and digesta passage in lactating cows. J. Dairy Sci. 84:2709-2720. 